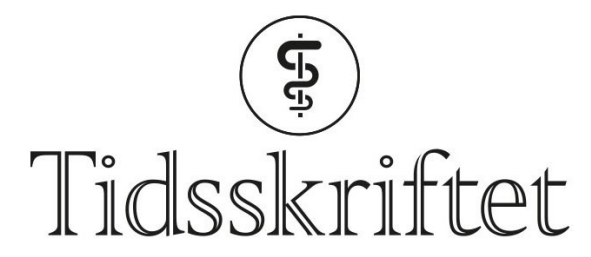

DEN NORSKE LEGEFORENING

\title{
Intravenøst lipom
}

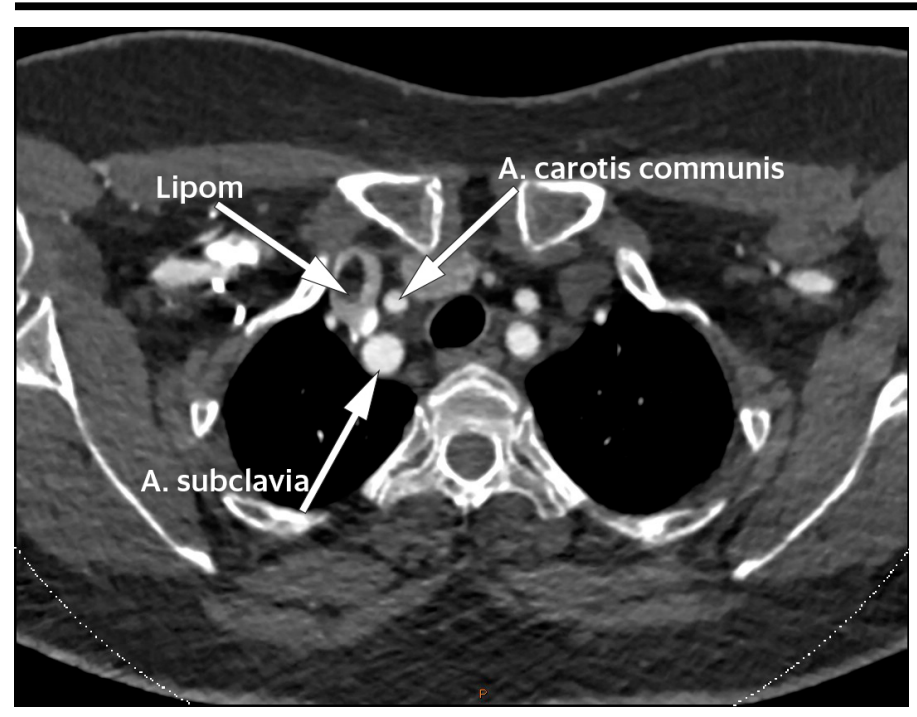

MEDISINEN I BILDER

\section{MORTEN VETRHUS}

E-post: morten@vetrhus.net

Karkirurgisk seksjon

Stavanger universitetssjukehus

Morten Vetrhus (f. 1968) er spesialist i karkirurgi og overlege.

Forfatter har fylt ut ICMJE-skjemaet og oppgir ingen interessekonflikter.

\section{LARS FJETLAND}

Seksjon for intervensjonsradiologi

Stavanger universitetssjukehus

Lars Fjetland (f. 1957) er spesialist i intervensjonsradiologi og seksjonsoverlege.

Forfatter har fylt ut ICMJE-skjemaet og oppgir ingen interessekonflikter.

En kvinne i 6o-årene med diabetes type 2 og hypertensjon ble utredet for mulig carotisstenose med CT-angiografi (kontrastforsterket CT). CT viste åpne arterier uten stenoser, men som et bifunn fant man en oppfylning i høyre vena brachiocephalica like etter konfluksen mellom vena subclavia og vena jugularis interna.

Oppfylningen målte $17 \times 8 \times 12 \mathrm{~mm}$ og hadde tetthet forenlig med fett (begge bilder). Det ble i tillegg gjort ultralyd og konkludert med at hun hadde et intravenøst lipom. Få tilfeller er beskrevet i litteraturen, de fleste lokalisert til vena cava inferior eller hjertet, men også beskrevet i vena brachiocephalica (1). Man kjenner ikke til i hvor stor grad intravenøse lipomer fører til venøs okklusjon, embolisering eller trombedanning (2). Enkelte anbefaler å fjerne lipomene, da kun histologisk undersøkelse kan skille mellom lipom og liposarkom $(2,3)$. Tross dette finner vi ikke ved søk i Pubmed at det er rapportert om intravenøse 
liposarkomer. Andre anbefaler kun å fjerne lipomene dersom de gir symptomer som følge av kompresjon eller smerte (4). Det synes som om mindre og asymptomatiske intravenøse lipomer kan observeres. For vår pasient er det derfor planlagt kontroll med MR om ett år.

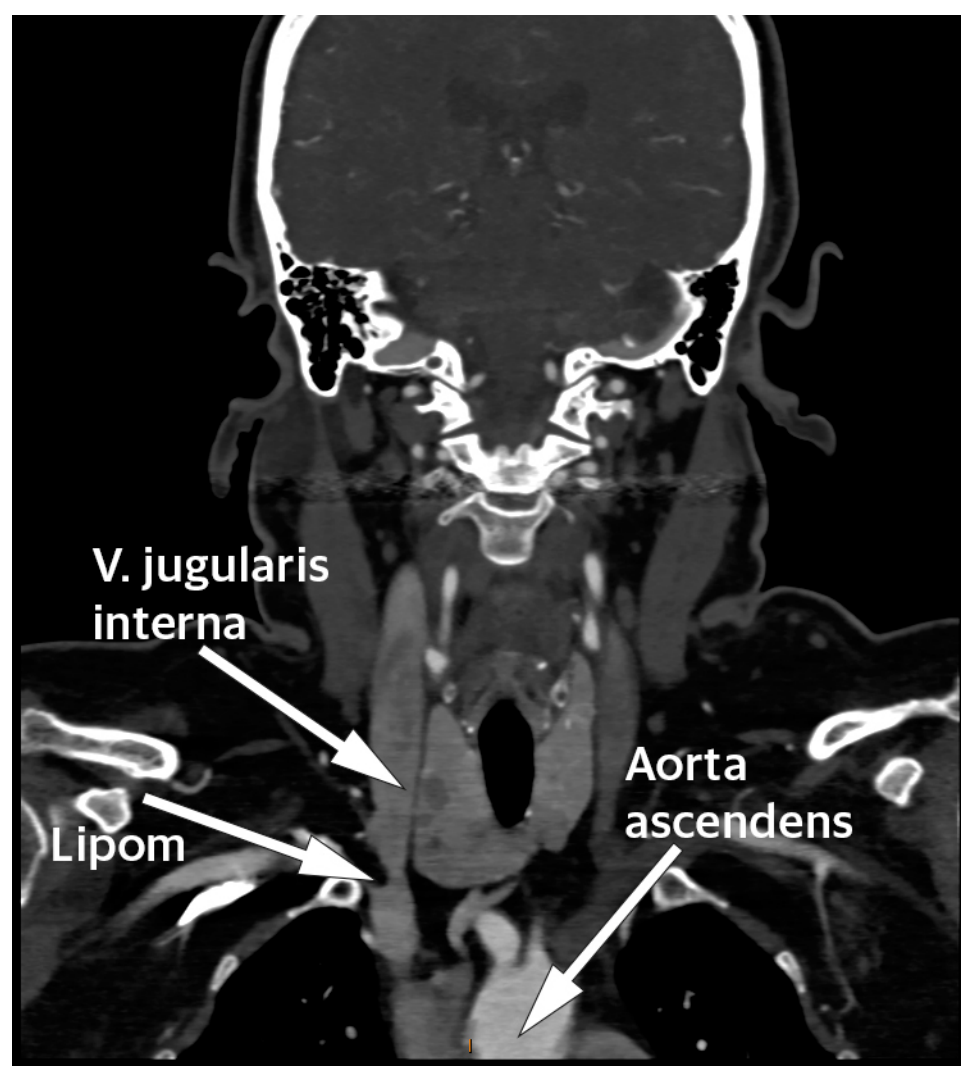

Intravenøst lipom er en sjelden tilstand med ukjent prevalens. I tillegg til liposarkom må andre differensialdiagnostiske tilstander overveies: andre sjeldne intravaskulære tumorer (hemangiomer, leiomyomer/sarkomer og angiosarkomer), lokalisert trombe eller ekstern kompresjon.

\section{LITTERATUR:}

1. Lococo F, Brandolini J, Hamelin-Canny E et al. Lipoma of the right thoracic inlet with intravascular extension and Fatty thrombus into the right brachiocephalic vein. Ann Thorac Surg 2013; 95: e129. [PubMed][CrossRef]

2. Yoon RH, Buzas CJ, Garvin RP et al. Intravascular lipoma of the internal jugular vein. J Vasc Surg Venous Lymphat Disord 2013; 1: 406 - 8. [PubMed][CrossRef]

3. Mordant P, Mercier O, Fadel E et al. Surgical resection of an intravascular superior vena cava primary lipoma. JThorac Cardiovasc Surg 2010; 140: 1437 - 8. [PubMed][CrossRef]

4. Bravi MC, Salvadei S, Scarponi P et al. Intravascular lipoma of the superior vena cava. Intern Emerg Med 2012; 7: 79 - 81. [PubMed][CrossRef]

Publisert: 28. november 2017. Tidsskr Nor Legeforen. DOI: 10.4045/tidsskr.17.0646

Mottatt 31.7.2017, første revisjon innsendt 7.10.2017, godkjent 20.10.2017.

(C) Tidsskrift for Den norske legeforening 2020. Lastet ned fra tidsskriftet.no 